HStud 24 (2010)2, 245-264 DOI: 10.1556/HStud.24.2010.2.6

\title{
THE INDIVIDUAL AND HIS LIMITS
}

\author{
DISCOURSES OF BORDER AND ETHNICITY IN TWO INTERWAR \\ VÖLKISCH NOVELS
}

GERGELY ROMSICS

Eötvös Loránd University, Budapest

Hungary

\begin{abstract}
This paper attempts to explore the identity politics component of two völkisch novels from the 1920s that grapple with the question of the identity of Germans from the old Austrian empire. The two authors, Bruno Brehm and Emil Lucka, were popular prose writers of the interwar period who partook of the general questioning, criticism and rethinking of the 19th century ideologies that occurred after the Great War. Their work - from the vantage point of the history of ideologies - may be interpreted as embedded in the language game of the German conservative revolution, especially in the currents that emphasized the permanent and essential characteristics associated with belonging to an ethnic group and the ethical consequences for individuals of this belonging. For this reason, this paper first briefly introduces post-1918 German völkisch ideology and proceeds to interpret the identity politics of the novels by making use of the key concepts of this strand of "young conservative" [jungkonservativ] thought. The key concept for interpreting the ambiguous experience of "being Austrian", i.e., belonging to the greater community of Germans, yet having had to suffer through centuries of living in a separate state became that of the borderland [Grenzland], a complex notion that dialectically united the experiences of heroically struggling to "remain German," while being threatened with loss of ethnic character through exposure to cosmopolitanism or assimilation. By showing how the discourse of Grenzland structures the narratives, the paper seeks to provide a reminder that the discourses of identity in early 20th century Austria were more complex than is often remembered: alongside late modernity, as represented and reflected by authors like Robert Musil and Elias Canetti, a different, more popular and more political trend also existed, which narrated the break-up of the Dual Monarchy and its aftermath in the context of the threatened existence of the Germans of the borderland.
\end{abstract}

Keywords: Volk, völkisch, Grenzland, Austrian identity, Austrian history, Bruno Brehm, Emil Lucka, conservative revolution, interwar literature 


\section{The Emergence of Völkisch Ideology and the Discourse about Austrian Identity}

Germany in the 1920s was, as contemporary observers noted, undergoing a vast process of intellectual and ideological fermentation. The meanings of (political) phrases and strategic concepts such as "people", "nation" and "state" were changing, while associations, periodicals and institutions were taking shape, ceasing to exist, undergoing transformations or falling into decline or insignificance. It was through this complex set of processes that an ideology reinterpreting the relationship between state and nation crystallized around the essential, ahistorical character of ethnic groups. Whereas before 1914 the dual Prussian and Austrian heritage, in other words the cult of the state, had marked public discourse in the German states, after 1919 a new actor gained increasing prominence in German history and the vision of a brighter German future: the Volk.

The Volk, the subject of the new cult, brought with it a reassessment of the past and a newly formed image of the future. The most intellectually active forces of the German right wing (both in Weimar Germany and the new Austrian republic) inquired into the question of the nature and substance of the (alleged) peculiar German quality, the core and character of the people's "soul" (Volkstum) that, independent of history, distinguished Germans from all other nations. In the history of ideas the products of this conception and the perspectives to which it gave shape are denoted with the expression völkischer Gedanke, or völkisch idea.

This thinking thrived on the disillusionment of many who saw how the Wilhelmine state had cracked and almost crumbled in 1918 and 1919, how Old Austria had vanished from the maps, and felt that history had "forsaken" the nation. New ideas proving that other, more enduring, forces would counterbalance political failure were keenly accepted by these same groups and individuals. Thus for many the notion according to which the German Volk was an eternal force, independent of the state and capable of defying history, was appealing. More so than ever, the prevailing winds of the new era were "German winds."

The völkisch idea, which became the canon of the new right under the Weimar Republic and was linked to notions of order and empire under the Third Reich while also penetrating the slightly "provincial" Austrian fora of political discussion, bore peculiarly German, anti-liberal and often anti-modern ideological connotations. The political divisions in the newly republican German societies, which represented an experience unfamiliar for public opinion, created a situation easily exploited by certain groups, as a consequence of which the völkisch idea exercised a significant influence as an ethical point of reference emphasizing organic unity (Koselleck, 1992, 389). In the conceptual system founded on the notion of the Volk, the individual was considered to be a "link in the chain" of a higher "völkisch unity," the task of which was the fulfillment of the mission derived from 
the "collective mentality" [Allgeist]. The body of the Volk, conceived as a collective subject, did not yield to precise description, although it was considered to be accessible to those that it "captured and conquered in their essence." After 1919 the peculiarity [Eigenart] of the Volk became the basis of interpretations of German destiny, defeat and greatness (Meyers, 1925, 820). ${ }^{1}$ Within the context of this discourse, the community of the Volk [Volksgemeinschaft] denoted the "core Volk" [Kernvolk] and all of the groups of peoples belonging to it, referring to "the spiritual affinity nurtured by common fate and common political conviction"(Brockhaus, 1934, 641, 658). In its final and most propagandistic incarnation under National Socialism the term eventually became a strategic ideologeme expressing transcendence of social disparities and differences of worldview and signifying bonds more general even than the state.

Most contributors to the völkisch language game, public intellectuals of highly varied backgrounds, also realized that making sense of the functions of geographical space and history were both necessary to produce coherent narrations about the life of the Volk. Both could carry positive and negative connotations alike, as they could equally be "conquered" by the Volk and "triumph" over its efforts and self-realization in the form of an ideal state. (Keyser 1933; Brocke, 1998, 82-3, 106-10). As Erich Keyser, a völkisch historian who gained fame primarily through his theoretical interests, put it,

\begin{abstract}
The distinctiveness of the German people can only be understood through its history, and its history can only be unraveled through analysis of the changes of the German Volk and the space that served as the scene of its development. Space is the expression of the force of the Volk to form history. Its extension and division into discrete segments mirror the prevailing life-force and direction of the German $\operatorname{Volk}(1931,353-4)$.
\end{abstract}

This conception has roots stretching back to the human geography of Friedrich Ratzel. Ratzel, who was in close professional contact with other forerunners of the conservative revolution (such as psychologists Wilhelm Wundt and Karl Lamprecht), "was never entirely able to overcome the influence of biological evolutionism in human history, particularly in his appraisal of states" (Faber, 1982, 391). On this basis he formulated his thesis concerning "growing political spaces," which served as a foundation for the explanatory mythology of the battle for territory. According to this thesis, states and peoples strive to achieve spatial realization, which at the same time is the proof of their vital force. Ratzel's conceptions of space and Volk therefore reciprocally presupposed and implied each other. On the one hand, the "roots of the Volk constitute a part of nature and reflect the characteristics of nature," while on the other they project this trait, inherited from nature, on the space that they occupy (Mosse, 1991, 27). The Ratzelian dic- 
tum, which from many points of view became a kind of mantra of Volkstumsforschung, offers a terse summary of this mutual implication: "All motion is a conquering of space [Raumüberwindung]." Accordingly, "the struggle over space is a life-or-death struggle" and the locations of peoples in space is from the outset a matter of conflict. According to the title of a novel popular at the time, however, the German people was a "Volk without Space" [Volk ohne Raum], so following Ratzel's dictum it was both logical and necessary for it to begin to expand to new territories (Schultz, 1989, 8). Both before and during the First World War scholars such as Joseph Partsch (1893) and Robert Sieger (1918) pursued work on the basis of similar premises. Their conclusions quite unsurprisingly urged the harmonization of the territory of the German language and the German Kulturboden (or "cultural soil," implying the territories of the influence of German culture) through the construction of a German Mitteleuropa, or in other words through an expansionist political platform.

Austria figured in the highly geography-conscious völkisch ideology first and foremost as a German space, if one existing constantly under threat due to its peripheral position. With regard to the earliest period, the myth of the German unity of late antiquity, which appears in the texts of the era as an indisputable article of faith, strengthened this interpretation. According to this conception, "[t]he appearance of the Germans and the evolution of the destiny of the German Volk in the eastern march [Ostmark] demonstrate the eternal and enduring unity of the German Volk across time. The central leadership ... gave commands that our ancestors executed and secured resources that they used." According to this conception, the Austrian "Stamm ... [was] a branch on the tree of the German Volk," which "as a consequence of its advanced position to the south and east ... acquired its character as a result of the forces of history and fate" (Beninger, 1939, 124; Brieger, 1935, 1; Andreas, 1927, 17).

There was consensus within the discourse that Austria was a part of the Volk that had taken the path of separate statehood [vereigenstaatlichtes Deutschtum]. In other words, the Germans of Austria were invariably and essentially German in every respect. The existence of a specific term for this concept, however, reflects not merely the propensity of the German language for compound words, but rather the extent to which the paradox of political separation and völkisch unity constituted a serious challenge to the (German) interpretations of (German) history, a paradox that was resolved in the discourse through the concept of Vereigenstaatlichung, a term that bore negative connotations. This constituted an $a b$ ovo value laden rejection of this path of development as a form of particularism, adhering to the mythos of the unified Volk state and presenting this historical change as a tragic episode in the loss of identity, the solution to which (the restoration of the unity of the Stauf era through the Anschluss) it saw as the 
conclusion to the romance-like narrative of the history of the Volk (Albert, 1934, 27-32).

The willingness of some authors to analyze the Austrian development within its own framework can be seen in the use of the terminological pair Österreich and Ostmark. While historicists tended to prefer the former, National Socialism and more radical scholarship and journalism used the latter. Most authors, however, made use of both, marking the dichotomy that derived from the notion of the autonomy of Austrian development on the one hand and the fundamental "unity" thesis of grossdeutsch ideology on the other. Among the latter one finds statements such as, "for one thousand years [Austria] has defended Germans by the Danube" and "a mere fifty years ago" it was excluded from being a part of the imperial German political framework. The former, however, found some validation in the generally accepted opposition of the characters of the "Prussian" and "Austrian" peoples, which had been formed by "a strong mixture of blood, Habsburg politics ... in brief history and fate," in spite of the fact that the Austrian Germans nonetheless "remained a branch on the tree of the German Volk," even if they had been transformed into a peculiar "pure, noble, and enchanting species." The decisive argument in the final interpretation and classification of the nature of Austrian character was the notion that "the German Volk is the soil from which Austrian culture sprang," and this culture therefore necessarily remained German, "apart from its international aristocracy and a few specific Viennese types" (Andreas, 1927, 16-17; Brieger, 1935, 3).

Within the context of this line of thinking, it became increasingly clear how one could (or should) grasp the monumental transgressions and failures of history. The Volkstumskampf, in other words the defense and expansion of the Volksboden and the preservation of the attachment and loyalty of the borderlands and their communities to the Volk, was established as an unambiguous measure of value. As the membership of the German communities of the borderlands to the Volk was considered to be a biological and social fact, it became a condition of the self-realization and self-fulfillment of the Volk as well. The preeminent political transgression had been and continued to be the denial of this fact and the resulting weakening of the Grenzvolk, a people always under threat in its defense, preservation and expansion of the borders. The recent past (displacement from the imperial German structure, totally separate statehood) was therefore thought of as an exception of history, and any return to it was seen as a vain delusion (Andreas, 1927, 18-19).

As is apparent, the völkisch discourses did not aim to disregard or deny entirely the differences between Austrian Germans and the Germans of the Empire, but rather merely to relegate these differences to a plane of lesser significance within the category of the concept of the Volk, and they accepted the existence of distinctive group characteristics (as in the case of other Stämme) given shape over the course of history. At the same time, however, these discourses made no allowance 
for the possibility that such characteristics might overshadow the power of the unity of the Volk, and they consequently vehemently rejected the cultural and historical concept of Austrian identity that sought through invocation of the notion of the "baroque man" (i.e., the Austrian as a product of Catholicism and Latinized civilization) to legitimize a heterogeneity within the broader German identity (this constitutes one of Brehm's chief points of contention, as will by analyzed below). This is explained by the fact that the figure of the autonomous "Austrian" constituted a challenge to the thesis of völkisch unity, appearing on the stage of history at the intersection of Latin and German cultural spheres as an autotelic and independent figure no longer interpretable in its totality within the cultural and semantic universe of Deutschtum.

The rejection of the mythos of the "Austrian man" and the subordination of the notion of Austrian identity to German völkisch history were paired with the minutely wrought concept of historical function, according to which "the faith of the southeastern strand of the German Volk in itself and its mission ... to form and guard the border ... has been an integral component of the Austrian state for a millennium" (Andreas, 1927, 18; Schumacher, 1934, 474). The concept of the border Germans constituted an essential element of the discourse through which the völkisch interpretation of Austrian identity was fashioned. Leading geographer Albrecht Penck situated the achievements of the culturally mixed communities of the borderlands in the foreground, and contrasted this idealized image with the pure culture and security of the core regions. In doing so, he elevated the dual battle for the preservation of völkisch character and the defense of the Volksboden to a factor determining the quality of membership in the Volk. As he observes,

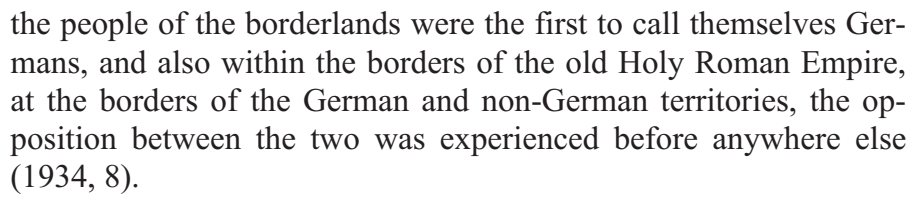

The concept of Volkstumskampf, which emerged as dominant in the discourse of the 1930s, became the most concise expression of the essence of this experience. In this interpretation, Austria figured as the scene of the perpetual Volkstumskampf, where it was necessary (in accordance with the dual nature of the Volkstumskampf) to fight for the Volkssiedelboden within the borders and defend the borders themselves (Schumacher, 1934, 455).

The canonical synthesis of "belonging" and "separation" that configured the image of the "Austrian man" emerged in the 1920s in the wake of innumerable treatises and articles, and was most famously summed up by Max Hildeber Boehm, a key figure of völkisch historiography. According to Boehm, 
Grenzland is not a racially pure territory. The peoples of the borderlands are almost an independent race, a race that is continuously uncertain about its own racial belonging, and is capable of rising if it catches the völkisch rhythm that keeps it in motion, swells its strength, and inspires it to acts of heroism $(1930,17)$.

One finds an example of the use of this general conceptual construct in the dichotomy established by Boehm, according to which the opposition between Germanization and the descent into a Central European, or Austrian, identity is the main thread of Austrian history. Their successive alternation corresponds to the "völkisch rhythm" and determines the direction of cultural transfer. Expansion belongs to the great eras of ascent, while the "Slavic influence" as well as all other forms of foreign penetration is synonymous with decline (Boehm, 1935, 135-7).

The Austrian segment of the German Volk, which had "dynamically lived" the experience of the border, assuming "its duty and fate" was thus assured a place of special significance (Boehm, 1932, 105). This undertaking constituted both "defense of the Empire" and "the southeastward expansion of the Volksboden" (Eschmann, 1933, 5). The logical conclusion of this line of thought was the view that the relationship of responsibility and service between border and core were reciprocal: the communities of the borderlands, which fought for the Empire and the Volk, justifiably expected the unconditional solidarity of the core territory. The interpretation according to which the Germans who had been born into the role of "Greater Germans" (in other words the Germans of the borderlands) were as in need of support as they were deserving it had been widespread before 1918, but following the First World War it quickly became dominant in völkisch thinking (Rapp, 1920, 176). Various forms of this solidarity were alleged to have existed in various historical periods, from the auxiliary forces provided by the Empire to support the Habsburgs in the wars against the Ottoman Turks to the masses of settlers and the dual alliance (Schüssler, 1937, 11). In the period following 1918, however, support first and foremost meant Anschluss, which was regarded as "rescue" of the abandoned and plundered Germans of Austria. In the worldview of the völkisch idea, "blood, race and the voice of the soul" all urged "the ideal of the grossdeutsch community," which had been strengthened again and again by the historical fate of the German Stamm. There could be no more fitting realization of this community than the recapture and recovery of the severed bloc of Germans of Austria as part of the emergent Volk state (Kamp, 1930, 19). Thus the task imposed by the events of 1918 was the reintegration of Austria (shorn of its völkisch character and consigned, in the wake of a long period of decline, to a separate fate as an after-effect of a repeatedly failed experiment of history) into German space, as well as its liberation from new economic and cultural pressures and constraints. All this would herald a new era of expansion and "the rising tide of the Volk" (Thalheim, 1931). 
In contrast to the ambiguous images of Vienna and Baroque greatness, rural Austria and the figure of the peasant both represent examples of concepts that bore exclusively positive connotations. While in the case of the former the dynamics of struggle, expansion and incursion proved decisive, the latter were connected first and foremost to the mythos of permanence and the preservation of volkisch character. The Austrian landscape and the figure of the ploughman became unambiguous themes of the concept of "pure" German ethnic character and Volkssiedelboden, symbolizing the enormous strength of the Volk untouched by the whims and commotion of history. As a representative of this mentality, the conservative revolutionary Viktor von Geramb urged a distinction in 1926 between the "original" culture of the Austrian peasant and the crucible of Vienna, contrasting the culture of the capital with the Volk consciousness of Tyrol and Styria (1926, 81-6). Like almost every other author contributing to the völkisch strands of the conservative revolution, Boehm too placed emphasis on Tyrol as the region that had preserved the character of the German Volk in its purest form. Others contrasted the culture of the Court and Church with the unspoiled life of the peasantry. The foundation of the latter, they felt, was "temperance, reason and sense of truth," and it "remained independent of Viennese clericalism," creating a culture "bound to the soil ... and German to the bone" (Andreas, 1927, 3, 18-19).

The völkisch literature on Austria gave form to the figure of the genuine Austrian through the concept of the peasant, abandoned by his own leaders, driven from the sphere of high politics, and forced to "practice" his Deutschtum through his everyday work of the land. This mytheme safeguarded the relationship between Austria and the German people, presupposing a society and Volk community too authentic for the politics of the dynasty, itself distant from the Volk, to be able to eliminate. Existing parallel to the decaying Austria of the Habsburgs, this peasant utopia represented a second Austria with more reality and substance, which in many cases took upon itself the tasks that, according to the authors, had been neglected by the Habsburgs.

Thus the Tyroleans came to figure as the most important defenders of the German areas of settlement, who assumed this task not simply on a regional level, but in a universal sense as well, first and foremost in 1809, when they had risen up against French troops with no support from the Habsburgs, and in the First World War, when they had distinguished themselves on every front (Stolz, 1926). This mythos of the Alpenland functioned as a metaphor of identity: it figured as a territory the history of which was one of heroic acts of self-defense and defense of the Volk. In a manner characteristic of völkisch ideology, this transformation became possible through the totalization of the concept of struggle: the effacement of the distinction between concrete and enduring, non-military threat, and its subordination to the concept of struggle, presented farming the land as being every bit as much a fight for the Volk as armed combat. The border conflicts of 1919, stylized 
by the grossdeutsch movement of Austria as symbolic initiation rituals of return to the Volk, made up the last chapter of this narrative. On the one hand these emphasized the cowardliness of the Habsburgs (and social democrats), who had abandoned their people, while on the other as "the first victorious acts of battle" they offered new affirmation of the topos according to which the Volk of the borderlands always fought the most heroically and unflinchingly in defense of its Volkstum (Brieger, 1935, 5-6; Nitschke, 1938, 7-9).

The mythos of the Austrian peasant was understandably intertwined with the defense of German territory. The second task, in contrast with the "intra-völkisch" [innervölkisch] calling, concerned the role in the "world of the peoples [Völkerwelt] of the southeast." As the expression Völkerwelt itself signifies, from the point of view of the "Empire of the Middle" [Reich der Mitte] created by the German people this territory was seen as one of chaos, backwardness, disorganization, in short political and cultural formlessness. It logically followed that German penetration in general was viewed as legitimate and indeed from the German point of view figured as an obligation and duty, as it would mean both the advancement of the populations of the region and the reinforcement of the geographical position of the German Volk, which was always considered to be under threat. In other words it would have constituted fulfillment of both "consciousness of mission" and "vital interest" (Böhm, 1932, 21). If Brehm's text offers an example of the dangers awaiting the individual who fails to firmly anchor his existence in the protective framework of the Volk, Lucka's novel demonstrates this, the second great völkisch observation about the Grenzland and its inhabitants. It seeks to provide testimony about those peasants who in the völkisch view engage in daily struggle to preserve or reclaim the old Volksboden for the German Volk, becoming truly mythical, and hence ahistorical, figures in the process.

\section{The Völkisch Novel as a Vehicle of Ideological Dissemination}

A discussion of the völkisch novel with the aim to illustrate a chapter in the history of ideologies understood as part of the histoire des mentalités calls for some justification. The novels discussed below were among those that constituted one of the most important channels through which the grossdeutsch idea came to permeate society in Germany and Austria. The novels in question, which belonged to the popular literature of the time, were often published in 20,000 or 30,000 copies. Several works by the perhaps best-known author, Bruno Brehm, sold more than 50,000 copies. It is thus difficult to overestimate their influence on society, and their significance is augmented by the fact that they applied the terminology of völkisch scholarship and ideology with remarkable precision, exemplifying and bringing it into close association with everyday life and experience. These novels 
can therefore be considered as instances of political writing, in that they functioned first as acts of identity politics and only then as works of fictitious literature (Barthes, 1972, 20-2). Their aim was not to prompt reflection or to give nuance to or throw into question the reader's conception of the world, but on the contrary to present a closed conceptual-poetic interpretive framework.

In narrative literature the classic genres of the völkisch tradition were the historical novel and the Heimatsroman, a narrative set in rural surroundings on the theme of love of hearth and homeland. They ensured the author an opportunity to present the genuine völkisch essence in the context of a utopian rural idyll or a recollection and evocation of the heroes of a "better" time. Prominent figures of völkisch literature typically thought of themselves as the narrators of a timeless Gemeinschaft, the harmonious, traditional community of the Volk, whose primary task was the presentation and propagation of "genuine" völkisch (in other words not cosmopolitan) culture (Geissler, 1964, 11-12). Of the Austrian representatives of this trend, Brehm, ${ }^{2}$ who later became a highly productive pamphleteer as a supporter of National Socialism, enjoyed particular success, and Emil Lucka, who renounced his Jewish ancestry and chose to become thoroughly German, was one of the most esteemed authors of (admittedly hard to read) völkisch novels, as well as a friend and later biographer of the turn of the century radical philosopher Otto Weininger. ${ }^{3}$ In the 1920 s and 1930s both were increasingly preoccupied with questions of national identity and the "German fate," subjects that they addressed in several of their novels.

For the Austrian German völkisch novelists these questions entered into a complex and fruitful relationship of reciprocal influence with the experience of völkisch identity (which constituted the foundation of their works), first and foremost in connection with the conflict-ridden memory of the multinational empire. The dogmas of the eigenständige Volk and the Volksgemeinschaft excluded from the outset the possibility of assimilation, even if in the case of Lucka the life of the author itself represented an extreme example of conversion. Lucka considered assimilation to be possible at most at the level of the individual, while regarding communities as self-sustaining and timeless. In his novel The Bleeding Mountain [Der blutende Berg] he turned to the theme of the Italian-Austrian conflict, which was continuously a topic of discussion between the two World Wars in Austrian public discourse, and Brehm dealt with the same theme in his novella The Border through the Middle of the Heart [Die Grenze mitten durch das Herz]. While the two works are substantially different (Brehm examines the psychology of identity, while Lucka considers the potential for independent agency on the part of the individual shaped by the community), their works both engaged in parallel discussions of conflicts between peoples, the Volkstumskampf itself. In spite of the different locales, the stylistic divergences, and the different plots, the two narratives are similar in their sociological poetics inasmuch as the frames of reference they 
mobilize to interpret their stories and the reinforcement they offer through the stories to these frameworks are parallel. Both consider the quality of ethnic affiliation to be absolute and both champion the moral imperative of attachment to völkisch character.

Similarly, both works have a bearing on the question of the Grenzlanddeutschtum, which was considered to be of central importance at the time. Significantly, in this case the word Grenze did not denote a political (state) border (for the borders of countries shift), but rather the fringes of the Volksboden.

After 1918 the popular völkisch novel brought about a radical subversion, in the context of the memory of the Habsburg Empire, of the theme of assimilation, familiar in the literatures of Central Europe. The dilemma of identity, which functioned as a strategic metaphor giving structure to narratives, and the return to völkisch character following the collapse of the multinational empire were the decisive motifs of this tendency and can be thought of as the literary reaction to the events of 1918 (Veiter, 1977, 165; Steinacher, 1934; Boehm, 1935, 73). The half-literary, half-political manner of writing defined itself as a memento and the imperial past as unnatural and beyond revival. It had two ideological functions: it endeavored to locate the German elements in the Habsburg past and organized the fundamental contradiction of this past, which lay in the tension between the Volk and the multinational empire, into a narrative plot. Each of the two novels under discussion here adopts one of these two interpretative possibilities, therefore giving apparently contradictory treatments of this past, which nonetheless converge in their anchoring of Austrian identity as unalterably and organically German.

This contradiction, therefore, exists only on the level of the sujet. The sociological poetics of the two works are essentially identical. Assimilation, a key question of the theory of identity underlying the texts, from this shared perspective is not a transgression; rather, it is an impossibility. Furthermore, as a struggle to preserve völkisch character, the Volkstumskampf is fate and condition, a yearning that stems from the nature of man, and rebellion against foreign influence. Thus identity can be betrayed at most, but never abandoned, as its fundamental site and substance do not reside in the freely chosen nation of a state, but rather in the Volk, an affiliation determined by birth. This radically collectivist utopia is the poetic core that constitutes the common distinguishing characteristic of the volkisch social and psychological novel. The varying approaches to the interweaving of the Habsburg past into the plot demonstrate that the Austrian grossdeutsch memory was itself ambivalent in its assessments of this legacy, as indeed was evident from the earlier discussion of historiography and journalism. On the one hand it assumed the unviability of the multi-ethnic or multinational state, while on the other it evinced some nostalgia for this political unity, attempting to establish a positive role for it in the master narrative of grossdeutsch historiography. 


\section{The Individual and His Limits: The Border through the Middle of the Heart}

The plot of Brehm's novella can be briefly summarized, as the functions of the events are exhausted in providing the background to the psychological inquiry (1938). Rudolph, the hero who hails from an old military family, visits Vienna as a child, where he reacts with jealousy to the discovery that his nephew, Francesco Perlini, is the favorite in his uncle's household, while he adapts with difficulty to the whims of his boorish although rich relative. They meet again more than ten years later, after the First World War, and the two veterans form an unusual friendship. Rudolph and Francesco have endless debates concerning the merits of southern culture and German culture, while the former pursues his legal studies and the latter, although also a student at the faculty of law, plans to write a description of the natural and human geography of the Karst mountains, which he loves passionately. Upon return from a one-year trip to Sweden, however, Rudolph discovers to his astonishment that his friend is terminally ill. During his second visit he hangs a Renaissance portrait of a woman on the wall of the hospital room and then takes leave of Francesco, who dies the following day. As this is happening, Rudolph discovers genuine love and prepares for his marriage to a ruddy-cheeked German girl.

The structure of the novel is relatively simple: the first chapter contains the story of Rudolph's trip to Vienna and the following three tell the story of the friendship that evolved between 1919 and 1921 (to the extent that one can determine the time frame with any precision). In this second segment of fictive time the narrative is essentially continuous and uninterrupted. We learn little about the year that Rudolph spends in Sweden, but this period has little more than a dramaturgical function as the period during which Francesco falls terminally ill. The personalities of the two protagonists and the world around them remain unchanged.

The configuration of settings is similarly simple, although it has a significant symbolic function. Before the war Rudolph lives in an unnamed town in Moravia, where the national struggle between Germans and Czechs is already raging at its height (Brehm, 1938, 22). Francesco lives in Trieste, under apparently agreeable circumstances. Although his parents are estranged from each other, his Italian father, an esteemed official in the bureaucracy of the Monarchy, sends him to a German school, while at home the two speak Italian (Brehm, 1938, 6-7). During the war his father flees to Italy, while Francesco (as a result of his father's defection) serves in a penal battalion in the Ukraine and Rudolph fights on the Italian front (Brehm, 1938, 29, 35, 51-5). It is significant, however, that the war only figures in the recollections of the characters, primarily in the form of allusion. It is a symbol and a faultline in history, falling between the era of the Monarchy and the new age 
of the nation state. After 1918 both protagonists live in Vienna, Rudolph as an Austrian German proud of his identity and Francesco as an Old Austrian who cherishes yearnings for the past, a refugee who is ashamed and afraid to go to the inner city of the capital of the new republic, which is shaped now by German culture (Brehm, 1938, 62, 67, 71-2).

The duality (or even contradiction) of the German and imperial past of Vienna (as the setting of the novella) offers a geographical backdrop rich with implications concerning the psychological questions and the dilemmas of identity. Rudolph is at home in Vienna, a German-speaking city in which one finds a splendid monument to the German Gothic, the Stephansdom, on the main square. For Francesco, however, Vienna is the last trace of the imperial identity and the only site in rump Austria that preserves something of the legacy of the Monarchy. At the same time, for the republic, which is embroiled in its quest for Anschluss, the capital is a new heart in which Francesco feels that there is no place for him. He expresses his sense of the simultaneous presence and irretrievability of the past in a dialogue with Rudolph: "This is a city of ghosts. It seems as if nothing were alive here, although that which died does not want to stay dead" (Brehm, 1938, 62).

Francesco's tattered K.u.K. uniform, which he wears both in protest and because of his poverty, seems increasingly strange in the slowly renascent city, from which he gradually feels himself to be physically excluded. He only dares go to Stephansplatz with Rudolph, preferring otherwise to withdraw to the symbolic space of the past, the library, where he studies the natural symbol of the one-time unity of the Empire, the Karst mountains, ground consecrated by the blood of soldiers of the Monarchy, and to relax he reads about the life of prince of Reichstadt (Brehm, 1938, 56-7, 68-70).

Francesco seeks his place in the space between cultures, but according to völkisch ideology as illustrated by Brehm this can only be a space of exile, a non-space outside identity which alone could offer some refuge to the individual. ${ }^{4}$ This is the source of the attraction to the pre-human, which offers an escape from the world circumscribed by the impenetrable borders drawn by the autochthonous characters of peoples. The symbol of the pre-human world in the novella is the Karst mountain range, which is Italian, Slavic and German, but perhaps first and foremost merely itself, an eternity that preceded nations. The soldiers' tombs, which in Francesco's view "consecrate" (Brehm, 1938, 56) the ground, are themselves testimony to the "pre-national." In death, the fallen, who have escaped the Volkstumskampf, are no longer Germans or Italians. Rather, they have returned to the soil of the Karst mountains, which knows no nations.

There is no similar escape in life, however. Taking refuge in the library, Francesco only figuratively leaves the divided world of nations. As mentioned, he finds his archetype in the figure of the prince of Reichstadt: living in the Imperial Court of Vienna, the son of Napoleon and Marie Louise suffered the same spiri- 
tual exile that Francesco is compelled to endure. In addition to finding refuge in his study of the Karst mountain range and the figure of the prince, Francesco resolves (or attempts to resolve) his crisis of consciousness in the memory of the Monarchy. By wearing his fraying uniform of a K.u.K. ensign, he continues to express his attachment to the old empire, but the novella implies that the Monarchy is not a historical edifice of an earlier era in which Francesco might find his place, but rather itself an undefined or amorphous formation, that was perhaps able for a time to lift the Germans within its border to new heights of history, but was nonetheless eventually doomed to fall.

Francesco served for years in a penal battalion to which he was transferred for no other reason than his father's voluntary exile. After the war he does everything to "reinterpret" those years, striving not to see them as punishment, but rather simply as military service. The novella, however, undermines the credibility of his attempts. The reader learns that almost all the other members of the battalion considered themselves to be Romanian, Czech, Ruthenian or Serb, and they all sang their own folk songs during the long nights in the Ukraine, awaiting all the while the eagerly anticipated fall of the Empire. A Romanian ensign turns to him at one point and says (and Francesco remembers his exact words years later), "you would have made the best Austrian of any of us, and you are now the most sad among us, but this Austria has not existed for some time now" (Brehm, 1938, 84).

This, according to Brehm, was the Monarchy: the penal battalion of the awakening nations, whose desire for secession was entirely understandable from the volkisch perspective. What remained of the legacy of the Empire, Brehm suggests elsewhere, was the work of the German Volk, in other words not the product of the meeting of peoples. In the long run the autochthonous character of each Volk and the imperative of a national homeland would inevitably assert itself. This, however, constitutes a judgment of the attempt of the protagonist to fashion an alternative "inter-national" identity for himself. Just as the Empire was destined to collapse, so Francesco's attempt was sure to fail, for it went against the fundamental laws of nature.

The psychological plot of the novella, which has a simple temporal structure and setting and very few characters, illustrates a single tenet (and from this point of view one may speak with some justification of the novella as the illustration of a thesis). As an anti-Heimatsroman, it depicts the desperate struggle of a young man who lives in denial of the primordial feeling of Gemeinschaft, trying to forget the "call of blood," which in Brehm's view is the only bearer of the promise of home. Francesco's fate is therefore tragic: his "homelessness" (understood as a kind of spiritual exile) in his chosen homeland exemplifies the impossibility of assimilation, the "terminal illness" of völkisch Lebensphilosophie, from which the only refuge is indeed death itself. 
According to the novella, ethnic identity can neither be cast aside nor transcended. It is connected to the timeless and the sphere beyond the individual, fundamentally influencing the psyche, tastes and desires of the individual. The Volk is eternal, the individual powerless. The bizarre and unnatural botchwork of the Monarchy had been a deceptive mirage of history (understood as the total of the discrete narratives of the fates of peoples closed within their own Volksgemeinschaft), and the last victim of this mirage, the last martyr of the multinational empire, was none other than Francesco Perlini.

\section{The Individual and His Potential: The Bleeding Mountain}

In his novel The Bleeding Mountain, Emil Lucka tells the story of a peasant family from South Tyrol (1931). In accordance with the tradition of the Heimatsroman, the novel has a simple structure but numerous characters, several of whom serve merely to illustrate a single idea on the part of the author. From this point of view, the plot-centric tale is in diametric opposition to Brehm's psychological novella. In this case too, however, the essence of the story can be briefly summarized. As a consequence of a series of coincidences, the Tscholl family awakens the suspicions of the Italian authorities. ${ }^{5}$ The father and his two sons, Dietrich and Valentin, come into conflict with the authorities. The daughter, Irma, kills an Italian gendarme officer and because of the many fines levied against the family, they lose their house. Eventually abandoning their home of some 300 years, the proud peasant family is compelled, following Dietrich's death, to leave the ancestral German lands.

The chronology of the novel is linear, with a single caesura of uncertain duration. The two halves of the novel tell the story of roughly one year in the mid-1920s. As the plot unravels, however, the parallel mythical plane comes to figure with increasing prominence, recalling the battle of Dietrich of Berne and the evil dwarf king Laurin (Lucka, 1931, 122, 198). The myth does not disrupt the linearity of the narrative, but rather reiterates and interprets the increasingly complex story by giving the trials of the Tyrolean peasant family the aura of an eternal struggle, in other words investing the simple tale with the attributes of eternal return. The mythic dimension does not figure in an independent chapter, nor even in subsections of chapters, but rather always in connection with the plot itself, and correspondingly fragmentarily, and with sudden transitions between the planes of myth and the present.

The story takes place in a rural mountainous district and a small town, settings that are clearly separated from each other by the structure of the narrative. This separation, however, implies similarity, not opposition. Both settings are sites of German culture that bear a common identity more profound than the differences 
in lifestyles: the German spirit, able and willing to adapt to circumstances, remains essentially unchanged. Similarly, the Italian incursions affect both settings and are identical in their character, their implements, and their aims: they seek to eliminate the distinctive culture that arose through many centuries of German work and assimilate the region (Lucka, 1931, 12, 36-41, 84-5).

At the same time, the symbolic site for the Germans of South Tyrol is unambiguously the mountain, as the title of the novel makes clear. The mountain, however, figures as an actual setting only in moments of particular significance in the narrative, precisely because of its symbolic importance. Everyday life takes place at its foot, in the village or the small town. The trade in smuggled goods, however, which is the only means of preserving relations with Austria and Germany, straddles the mountain, while the deliberate deforestation denudes it, exemplifying ruthless Italian exploitation of the land, in contrast with the harmonious German lifestyle in close proximity to nature. In the end Dietrich's confrontation with the Italian gendarme officer takes place on the mountain as well, as did the struggle between Dietrich of Berne and the dwarf king, and his beloved flings herself from its heights with his dead body in her arms (Lucka, 1931, 201-4).

The key to the symbolic significance of the mountain is the well on its slope, the water of which turned to blood in 1809 , at the time of the Hofer uprising. At a dramatic moment in the unraveling of the plot, when the youths swear their allegiance to the German and Austrian flags with the priest, the waters again are bloodied (Lucka, 1931, 46-7, 169-71). Thus the mountain to which they have retreated to take their oath is the site of memory and identity. It is a central metaphor the basis of which, however, is not some sort of atmospheric correspondence, but rather the signification of the mythical battle of Dietrich of Berne on the one hand and the traditions of several centuries of life in the Alps on the other. The bloody water is both a reminder and a warning: it alludes to the dangers threatening the Tyroleans, symbolically calling for individual sacrifice.

As the many threads of the plot unravel, no doubt remains concerning the epic nature of the struggle. The school inspector Buttazeoni rapes Philomena, the daughter of the teacher Eisenstecken, thereby weaving another mythical element into the tale. Following the dismissal of Eisenstecken there is a spontaneous gathering of villagers at the home of the Tscholl family, where the Tyrolean, imperial (Habsburg) and German flags are brought out from their secret hiding place. Eisenstecken finds a church painting of the 1809 uprising, which he had hidden in 1918, and just before the arrival of the gendarmerie the villagers assembled sing a folk song about Andreas Hofer (Lucka, 1931, 51-8).

The various events all bear the semes of Volktstumskampf, referring in this case to the struggle fought in the cause of preserving the identity of the communities of Germans severed from the body of the German Volk (Haar, 2000, 49). In and of itself, however, the interpretation of the novel as a whole as a narrative of 
Volktstumskampf would not be adequate. The text is structured into narrative through the function of the individual in this struggle (as a combination of duty and opportunity), or rather the parallel articulation of this function in the accounts of the fates of Dietrich and his father. This characteristically collectivist ethics creates the system of morals, both dissolving and strengthening the individual, who can only exist authentically as part of the Volk, but who finds and even creates himself through this existence. In this interpretative framework the memory of the "German" Monarchy was naturally integrated into the history of Volktstumskampf, as is apparent on the level of symbols from the reference to the use of the two flags, that of the Habsburg Empire and that of Germany, side by side. This motif recurs in the father's attachment to the flags, for the possession of which he is arrested:

But he would not give them the flags! And he thought of the people who sat languishing in prison, because they could not become Italians out of Austrians, or Welsh out of Germans. He was a captive on his own soil, a servant in his home (Lucka, 1931, 23).

As this citation makes clear, membership in the state was tantamount to membership in the Volk. To be Austrian and German was, for Lucka, not a contradiction, just as the memory of the Monarchy and German völkisch memory not only were harmonious and compatible, but were inseparable, for instance in the mythos of the Hofer uprising, as the most significant point of reference of Tyrolean identity.

\section{Conclusions}

The novels of Brehm and Lucka both consider the question of the potentials of the individual in the formation of his relationship to a community in the context of the same ideological system of references. The common perspective of the two novels is the völkisch idea, which takes first and foremost the conceptual pair of attachment and belonging as its starting point in relation to the individual. In völkisch ideology (and thus in the Heimatsroman), membership in a community is not a choice. Rather, it constitutes a given attribute and a task, the recognition of which is the challenge set for the individual, being in this sense identical with the way in which the völkisch community itself is conceived. In his novel Brehm examines the attempt (in his view doomed to failure) to escape from the Volk and an identity the roots of which lie in the Volk, while Lucka considers the potential for the realization of the duties and freedoms stemming from völkisch consciousness.

From the point of view of an assessment of the new-Austrian [neuösterreichisch] prose that developed in the period following the dissolution of the Austro-Hungarian Monarchy, the two novels presented here as paradigmatic and 
representing a significant segment of the popular literature at the time are revealing. Aesthetically they do not bear comparison with the works of Elias Canetti or Joseph Roth, for instance, and they have little or no significance in the context of literary history (from the point of view of canon formation). Nonetheless, they were printed in huge numbers of copies, and thus not only are of interest as sources in the study of the histoire des mentalités, but in several aspects offer more faithful representations of the era than the works of such writers as Robert Musil or Karl Kraus, which were of significance only for a small layer of the intellectual and cultural elite. Understandably, the Habsburg renaissance of the past two decades established canons in every field of scholarship laying emphasis on the languages and manners of writing in the discourses of the past that can be read as part of a dialogue with our age, discovering in them aesthetic and conceptual prefigurations and anticipations of the present. The historian, however, cannot restrict himself to investigations of the past in which dialogues between with the historical horizon follow naturally. She must strive to present intellectual currents which were as significant socially at some point in the past as they are alien today, and the language of which, indeed, she may not even speak.

It is therefore useful to remember that Brehm and Lucka were themselves heirs to the legacy of the Monarchy, and its utter collapse prompted them (as it did Roth, Kraus and others) to reconsider their circumstances. In the situation created by the disillusionment following the fall of the Monarchy, the two novels under discussion constituted documents of the range of ideas of the völkisch movement, which for many were gradually becoming increasingly irresistible because they offered, through the grossdeutsch idea, a way out of the intellectual and political crisis. They could be considered as responses to a painful calamity: the experience of the historical failure of the Vielvölkerreich (the multinational empire), the death throes of which were seen as dating back to 1866-67, constitutes the metaphorical soil in which their tenets and precepts took root. As responses, they cannot be separated from the Habsburg Empire, even if they constitute a rejection of the ideals that held it together. For these texts vehemently reject the possibility of assimilation and the assumption or transformation of identity (whether imperial or völkisch), just as they deny the potential of historical process and political art to foster new identities. In response to the fluctuations of history, they gesture to the Gemeinschaft as a universal and timeless measure of value, and they derive the position of the individual in the world from his relationship to the völkisch community. In this discourse, the border(lands) emerged as the true frontier of German experience. These wild countries - be they of the heart of Francesco Perlini or the Alps themselves - were presented as mortally dangerous for the individual and the community, yet also calling for and serving as the backdrop for great deeds. The Grenzland was thus truly the space of Grenzsituationen: the border became the liminal, permitting a deeper and truer understanding of key knowledge required for the functioning of the individual, the tribe and, ultimately, the nation. 


\section{Works Cited}

Albert, Wilhelm (1934) Grenzlanddeutschtum: Ein Hilfsbuch. für Unterrichtsanstalten aller Art (Nürnberg: Korn).

Andreas, Willy (1927) Österreich und der Anschluss (Berlin: Deutsche Verlaggesellschaft für Politik und Geschichte).

Barthes, Roland (1972 [1955]) Le degré zéro de l'écriture. Suivi de nouveaux essais critiques (Paris: Seuil).

Beninger, Eduard (1939) Germanischer Grenzkampf in der Ostmark (Vienna: Frick).

Boehm, Max Hildebert (1930) Die deutschen Grenzländer, 2nd ed. (Berlin: Reimar Hobbing).

Boehm, Max Hildebert (1932) Das eigenständige Volk: Volkstheoretische Grundlagen der Ethnopolitik und Geisteswissenschaften (Göttingen: Vandenhoeck \& Ruprecht).

Boehm, Max Hildebert (1935) Volkstheorie und Volkstumspolitik der Gegenwart (Wissenschaftliche Forschungsberichte zum Aufbau des neuen Reiches. Heft 4) (Berlin: Junker \& Dünhaupt).

Böhm, Anton (1931) 'Österreichs Wesen und Wandel in der Zeit', in Friedrich Heiss and Arnold Hillen Ziegfeld (eds) Bekenntnis zu Österreich (Berlin: Volk und Reich), 15-31.

Brehm, Bruno (1938 [1922]) Die Grenze Mitten durch das Herz (Munich: Piper).

Brieger, Konrad Kurt (1934) Das alte und das neue Österreich (Munich: Hilfsbund der Deutsch-Österreicher).

Brocke, Bernhard vom (1998) Bevölkerungswissenschaft Quo vadis? Möglichkeiten und Probleme einer Geschichte der Bevölkerungswissenschaft in Deutschland (Opladen: Leske \& Budrich).

Der grosse Brockhaus, 1934. Der grosse Brockhaus, Bd.15 (Leipzig: Brockhaus).

Eschmann, Ernst Wilhelm (1933) Vom Sinn der Revolution (Jena: Diederichs).

Faber, Karl-Georg (1982) 'Zur Vorgeschichte der Geopolitik: Staat Nation und Lebensraum im Denken deutscher Geographen vor 1914', in Heinz Dollinger (ed.) Weltpolitik, Europagendake und Regionalismus: Festschrift für Heinz Gollwitzer zum 65. Geburtstag (Münster: Aschendorff), 389-406.

Geissler, Rolf (1964) Dekadenz und Heroismus: Zeitroman und völkisch-nationalsozialistische Literaturkritik (Stuttgart: Deutsche Verlagsanstalt).

Geramb, Viktor von (1926) 'Ein Brief aus Österreich', Volk und Reich, Vol. 2, 78-92.

Haar, Ingo (2000) Historiker im Nationalsozialismus: Die deutsche Geschichtswissenschaft und der 'Volkstumskampf' im Osten (Göttingen: Vandenhoeck \& Ruprecht).

Kamp, Ignaz (1930) 'Biologische und Kulturpolitische Skizzen über Deutschland und Österreich', in August Gallinger (ed.) Deutsch-Österreich: Kulturprobleme (Munich: Hübner), 18-57.

Keyser, Erich (1931) 'Entwicklung und Aufgaben der bevölkerungsgeschichtlichen Forschung in Deutschland', Historische Viertelsjahrschrift, Vol. 25, 353-70.

Keyser, Erich (1933) 'Die völkische Geschichtsauffassung', Preußische Jahrbücher, Vol. 234, $1-20$.

Koselleck, Reinhart (1992) 'Volk, Nation, Nationalismus, Masse', in Otto Brunner et al. (eds) Geschichtliche Grundbegriffem Bd. 7 (Stuttgart: Klett-Cotta).

Lucka, Emil (1931) Der blutende Berg. Ein Roman aus Südtirol (Leipzig: Hesse und Becker).

Meyers Lexikon (1925) Meyers Lexikon Bd. 12 (Leipzig: Meyer).

Mosse, George L. (1991) Die völkische Revolution, 2nd ed. (Frankfurt a.M.: Fischer), 27.

Nitschke, Richard (1938) Österreich, ein Land des deutschen Reiches (Breslau: Handel).

Partsch, Joseph (1893) Schutzgebiet des Deutschen Reiches (Berlin: Reimer).

Penck, Albrecht (1934) Nationale Erdkunde (Berlin: Buchholz \& Weisswange).

Rapp, Adolf (1921) Der deutsche Gedanke, seine Entwicklung im politischen und geistigen Leben seit dem 18. Jahrhundert (Bonn: Schroeder). 
Schultz, Hans Dietrich (1989) 'Einleitung', in Idem (ed.) Geographie und Nationalsozialismus: 3 Fallstudien zur Institution Geographie im Deutschen Reich und der Schweiz (Kassel: Gesamthochschule), 3-51.

Schumacher, Rupert von (1941) 'Die Ostmark und der Donauraum', in Karl Haushofer and Hans Roeseler (eds) Das Werden des deutschen Volkes: Von der Vielfalt der Stämme zur Einheit der Nation (Berlin, Propyläen), 439-483.

Schüssler, Wilhelm (1937) 'Deutsche Einheit und gesamtdeutsche Geschichtsbetrachtung', in Idem. Deutsche Einheit und gesamtdeutsche Geschichtsbetrachtung (Stuttgart: Cotta) 1-22.

Sieger, Robert (1918) Der österreichische Staatsgedanke und seine geographische Grundlagen (Vienna: Fromme).

Steinacher, Hans (1934) Volkstum jenseits der Grenze (Stuttgart: Francksche).

Stolz, Otto (1926) 'Tirols Geschichte als deutsches Grenzland', Volk und Reich, Vol. 2, 220-8.

Thalheim, Karl C. (1931) Das Grenzlanddeutschtum: Mit besonderer Berücksichtigung seiner Wirtschafts- und Soziallebens (Leipzing and Berlin: de Gruyter).

Veiter, Theodor (1977) Nationalitätenkonflikt und Volksgruppenrecht im 20. Jahrhundert, I-II (Vienna: Braumüller).

\section{Notes}

1 The cited popular lexicon of the era gives the following definition of völkisch: "a common term of recent coinage the use of which, like volklich, is widespread," and "the German equivalent of "national"'.

2 Bruno Brehm (1892, Ljubljana - 1974, Altaussee; also known by the pseudonym Bruno Clemens), a popular novelist whose trilogy on the collapse of the Monarchy has been translated into almost all the languages of Europe. In the 1930s he associated with members of the National Socialist party, and during the Second World War worked as a propagandist. In the final stages of his career as a novelist he turned against his own Nazi past, although he did not distance himself from the national program. His works include the following: Apis und Este, 1931; Das war das Ende, 1932; Weder Kaiser noch König, 1933; Zu früh und zu spät, 1936; Auf Wiedersehen, Susanne, 1939; Die sanfte Gewalt, 1941; Der fremde Gott, 1948; Der Lügner, 1949; Aus der Reitschuln, 1951; Das zwölfjährige Reich I-III., 1960/61; Warum wir sie lieben, 1963; Am Ende stand Königgrätz, 1965.

3 Emil Lucka (1877, Vienna - 1941, Vienna), writer, dramatist and essayist. In his youth he was a close friend of Weininger, whose ideas exerted a strong influence on him. He defined the concept of race from a historical perspective, but at the same time was considered a representative of German völkisch literature, his Jewish background notwithstanding. His works include the following: Otto Weininger, 1905; Isolde Weißhand, 1909; Grenzen der Seele, 1916; Heiligenrast, 1919; Dostojewski, 1924; Michelangelo, 1930; Tod und Leben, 1907; Am Sternbrunnen, 1925; Der blutende Berg, 1931; Der Impresario, 1937.

4 In the heat of one of the debates Francesco cries out, "We lost the war? I didn't just lose the war! I am left with nothing, nothing in the world! I don't even know what to seek, no matter how badly I yearn to find something" (Brehm, 1938, 57).

5 The family's name is revealing: Scholle, or soil. It represents the bond between the German peasantry and the land, which is inseperable from the Volkstum and the identity of the individual. 